Avoimesti luettavissa osoitteessa http://journal.fi/ainedidaktiikka

\title{
Pedagogisen Haltijan kuiskaus -materiaalin soveltaminen varhaiskasvatuksessa J. A. Hollon kasvatusajattelun luentana
}

\author{
Sara Sintonen, Alexandra Nordström, Heidi Sairanen ja Kristiina Kumpulainen
}

Kasvatustieteellinen tiedekunta, Helsingin yliopisto

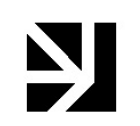

Artikkeli liittyy kulttuurikasvatuksen toteuttamiseen varhaiskasvatuksessa. Tarkastelemme, kuinka sivistyskasvatus heijastuu varhaiskasvatuksen opettajien erilaisissa tavoissa soveltaa erästä suomalaisiin luontouskomuksiin ja myytteihin liittyvää pedagogista materiaalia. Sivistyskasvatuksella viittaamme J. A. Hollon (1895-1967) ajatuksiin kasvatuksesta. Hollon sivistyskasvatusajattelun ytimessä ovat muиn muassa luovuus, mielikuvittelu ja ilo, jotka kiteytyvät älyllisen, eettisen, esteettisen ja toiminnallisen kasvatuksen toteuttamisessa. Kulttuuri, sivistys ja taiteet olivat Hollolle tärkeitä kasvatusta ohjaavia seikkoja; myös tarinoiden merkitys ja voima korostuvat Hollon ajattelussa. Nämä näyttäytyvät tutkimuksessamme tärkeinä varhaiskasvatukseen liittyvän kulttuurikasvatuksen ja pedagogisen kehittämisen taustoittajina.

Juho August Hollo, kulttuurikasvatus, luontouskomukset, sivistyskasvatus, varhaiskasvatus

Lähetetty: 10.3.2019

Hyväksytty: 2.6.2020

Vastuukirjoittaja: sara.sintonen@helsinki.fi

DOI: $10.23988 / \mathrm{ad} .79782$ 


\section{Johdanto}

Kuinka käsitellä vanhoja luontouskomuksia ja myyttejä varhaiskasvatuksessa, vai onko niitä syytä käsitellä ollenkaan? Mitä tekemistä niillä on kulttuurikasvatuksen kanssa? Tämä artikkeli liittyy suomalaiseen kulttuurikasvatuksen pedagogiseen toteuttamiseen varhaiskasvatuksessa. Ymmärrämme kulttuurikasvatuksen jonkin meille yhteisen aineellisen tai aineettoman resurssin jakamisena, jossa kasvatuksen keinoin pyritään osoittamaan ja uudelleen heijastamaan niihin liittyviä merkityksiä (vrt. Stark, 2016, s. 73). Ymmärrämme kulttuurikasvatuksen myös varhaiskasvatukselle sekä esi- ja perusopetukselle annettuna kulttuuritehtävänä (Kangas \& Rusanen, 2018). Varhaiskasvatus sekä esiopetus ovat eheytettyä opetusta, joissa asioita ja ilmiöitä tarkastellaan laaja-alaisesti eri oppimisen alueiden (varhaiskasvatus) ja oppimisen kokonaisuuksien (esiopetus) avulla. Kulttuurikasvatus asettuu Minä ja meidän yhteisömme -oppimiskokonaisuuden alle, jota varhaiskasvatuksessa toteutetaan muun muassa pohtimalla "lähiyhteisön menneisyyttä, nykyisyyttä ja tulevaisuutta" (Opetushallitus, 2018, s. 45) ja esiopetuksessa käsittelemällä "lapsia kiinnostavia muita historiallisia tapahtumia, henkilöitä, kulttuureja ja kulttuuriperintöä" (Opetushallitus, 2014, s. 34). Haltijan kuiskaus -materiaalin "pedagogisena tavoitteena on herättää kiinnostusta suomalaista luontoa ja vanhoja uskomuksia kohtaan monesta eri näkökulmasta. Tehtävät houkuttavat myös monella eri tavalla tarkkailemaan, pohtimaan, keksimään ja kokeilemaan itse" (Erfving ym., 2017). Materiaalin avulla voidaan käsitellä asioita ja ilmiöitä historiallisesta, eettisestä, katsomuksellisesta ja yhteiskunnallisesta näkökulmasta erilaisin vuorovaikutuksellisin keinoin, kuten sanallisen ja kuvallisen ilmaisun avulla, eheyttäen eri tiedonaloja: varhaiskasvatus ja esiopetus ovat eri tiedonaloja sisältävää eheyttävää pedagogista toimintaa. Erityisesti luontoon liittyvät myytit ja uskomukset ovat tärkeä osa kulttuuriperintöämme ja siten ne liittyvät myös kulttuurikasvatukseen. Suomalaisessa varhaiskasvatuksessa kulttuurikasvatus on yksi monipuolisen pedagogisen sisällön ja toiminnan kivijalka (Opetushallitus, 2018).

Olemme kiinnostuneita siitä, miten varhaiskasvatuksen pedagoginen toteuttaminen heijastelee erityisesti Juho August Hollon (1895-1967) kasvatusajatuksia varhaiskasvatuksen opettajien toimiessa kulttuurikasvattajina sekä toteuttaessa varhaiskasvatussuunnitelman perusteita (Opetushallitus, 2018). Varhaiskasvatussuunnitelman perusteissa (Opetushallitus, 2018, s. 21) kasvatusta kulttuuriin pidetään muun muassa yhtenä ekososiaalisen sivistyksen perustana. Tässä tutkimuksessa varhaiskasvatuksen opettajat eri puolilla Suomea ovat käyttäneet ja soveltaneet kehittämäämme Haltijan kuiskaus -nimistä materiaalia eri tavoilla tavoitteenaan sisällyttää opetukseen suomalaisiin luontouskomuksiin ja myytteihin liittyviä sisältöjä ja tarinoita. Haastatteluaineistoa analysoimalla tarkastelemme, kuinka hollolainen kasvatusajattelu heijastuu varhaiskasvatuksen opettajien erilaisissa tavoissa soveltaa Haltijan kuiskaus -materiaalia pedagogisessa työssään. Lähes sata vuotta sitten vaikuttaneen kasvatustieteilijä Juho Hollon kasvatusajattelun ytimessä ovat luovuus, mieli- 
kuvittelu ja ilo, jotka kiteytyvät älyllisen, eettisen, esteettisen ja toiminnallisen kasvatuksen toteuttamisessa. Kulttuuri, sivistys ja taiteet olivat Hollolle tärkeitä pedagogiikkaa ohjaavia seikkoja; Matti Tanelin (2012) hollolaista kasvatusfilosofiaa analysoivan laajan tutkimuksen mukaan myös tarinoiden merkitys ja voima korostuvat Hollon kasvatusajattelussa.

Haltijan kuiskaus on suomalaisiin luontouskomuksiin ja myytteihin liittyvä pedagoginen materiaali. Tuotimme sen osana Monilukutaitoa Opitaan IIolla (MOI) -kehittämisohjelmaa, joka on pienten lasten monilukutaidon kehittymisen tukemiseen suunnattu Opetus- ja kulttuuriministeriön rahoittama kärkihanke (Kumpulainen ym., 2018). Haltijan kuiskaus on pyritty luomaan esteettisesti kiinnostavaksi ja pedagogiselta luonteeltaan avoimeksi materiaaliksi, jolloin siihen sisältyviin tehtäviin ei ole oikeita ratkaisuja, eikä ole yhtä oikeaa tapaa käyttää sitä. Haltijan kuiskaus kannustaa avoimella tavalla opettajia toteuttamaan kulttuurikasvatusta siten, että siinä kulttuurinen osallisuus ympäristöön muodostuu myös ympäristön omakohtaisen kokemisen kautta (ks. Puolamäki, 2008, ss. 6061). Laajemmin kyse on pyrkimyksistä sivistää lasta ja tukea hänen kehitystään ihmisenä kasvamisessa (Rauste-von Wright \& von Wright, 1994; Tornberg \& Venäläinen, 2008).

Aineistomme teema- ja sisällönanalyysin keinoin ( $\mathrm{mm}$. Braun \& Clarke, 2006) tarkastelemme, miten avoimen, esteettisesti kiinnostavan ja toiminnallisuuteen kannustavan materiaalin avulla voidaan innostaa varhaiskasvatuksen opettajia kehittämään pienten lasten luonto- ja kulttuurikasvatusta digitaalisella ajalla, perinteitä kunnioittaen. Pohdimme, heijasteleeko aineistomme, joka koostuu varhaiskasvatuksen opettajien eri tavoin dokumentoimista, lasten monimodaalisesti tuottamista Haltijan kuiskaus -sisällöistä hollolaista kasvatusajattelua; nykykäsitys kasvatuksesta ja opetuksesta on kuitenkin tuonut mukanaan enemmän lapsia osallistavia ja heidän toimijuuttaan korostavia työtapoja ja välineitä (Opetushallitus, 2018), jotka soveltuvat erinomaisesti myös kulttuurikasvatuksen pedagogisiin tarpeisiin. Tarkastelemme myös, kuinka esteettisen, toiminnallisen materiaalin soveltaminen ja käyttö osoittavat suomalaisen varhaiskasvatuksen opettajien pedagogisen vahvuuden lasten oman luovuuden ja mielikuvittelun hyödyntämisessä, seuraten täten hollolaisia jälkiä.

\section{J. A. Hollon kasvatusajattelu ja sivistyskasvatus}

J. A. Hollosta monille muistuu ensimmäisenä mieleen hänen ajatuksensa kasvatuksesta kasvamaan saattamisena, joka esiintyy hänen teoksessaan Kasvatuksen teoria (Hollo, 1927, ss. 64, 120-121). Esimerkiksi Risto Ikonen (2000) pitää kyseistä lausahdusta suomalaisittain katsottuna yhtenä tunnetuimpana kasvatusta koskevana luonnehdintana. Mitä Hollo itse asiassa tällä tarkoitti? Kasvatus kasvamaan saattamisena on hyvin lavea ilmaisu ja Ikosen (2000) mukaan lähes runollinen, ja sen tieteellisteoreettiset perusteet ovat kevyet. Myös Asko Karjalainen (1986) huomauttaa Hollo-tulkinnassaan, että Hollo ei sinänsä problematisoinut kasvun käsitettä, vaan hänen mukaansa "kasvu" tarkoitti Hollolle luonnollisen elämän perusvoimaa; tällöin kasvatus on kasvatissa olevan hyvän kasvamaan saattamista. Ikosen (2000, s. 119) mukaan Hollo kuvaakin Kasvatuksen teoriansa kyseisessä kohdassa kasvamista nimen omaa luontoperäisenä ilmiönä, jolloin kasvatuksen tarkoituksena on lähinnä luoda tilaa luonnollisten kasvatusmahdollisuuksien toteutumiselle. Harni ja 
Saari (2016, s. 26) toteavat saman asian ilmentävän kasvatuksen asettamista elämän palvelijaksi eli toisin sanoen "suotuisimpien olosuhteiden luomista spontaanille ja selittämättömälle kasvamisvoimalle". Näin ajateltuna kasvatusta voidaan pitää inhimillisen kehityksen sosiaalisena ulottuvuutena.

Taneli (2012, s. 13) avaa väitöskirjansa johdannossa Hollon ajatuksen kasvatuksesta kasvamaan saattamisena tiivistämällä, että Hollolle "kasvatus on vuorovaikutuksellista, ainutkertaista, pakotonta, kasvatettavaan kunnioittavasti suhtautuvaa ja hänen yksilöllisiä kasvumahdollisuuksiaan edistävää elämänlaajuista toimintaa”, ja että hollolaisen sivistyskasvatusajattelun tavoitteena on hyvä elämä. Hän tarkentaa, että "kasvamaan saattamista" voi luonnehtia myös muilla ilmaisuilla kuten elämään auttaminen, ohjaaminen, keskeneräisyys ja loputtomuus. Taneli (2012, ss. 40-43) tulkitsee muun muassa Puolimatkaan (1999) nojautuen Hollon kasvamaan saattamisen aristoteelisessa mielessä tapahtuvaksi kasvatusprosessin tietoiseksi ohjaamiseksi. Tätä ohjaamista kehystää ihmisen kehityksen perustana olevia luovuttamattomia arvoja.

Taneli (2012) käyttää väitöskirjassaan termiä "sivistyskasvatus" pääkäsitteenä kuvaamaan ja luonnehtimaan hollolaista fenomenologishermeneuttista kasvatusajattelua. Hän määrittelee sen samalla kasvamaan saattamisen kehykseksi (Taneli, 2012, s. 15) eli ikään kuin toimintavälykseksi, jonka puitteissa kasvattaja työtään tekee. Hollolaisittain sivistyskasvatus ei tarkoita jonkin kulttuurisisällön tai -perinteen siirtämistä, vaan ennen kaikkea prosessia, jonka kautta jokaisella sukupolvella on mahdollisuus kehittyä inhimilliseen täyteen mittaansa ja elää hyvää ja onnellista elämää.

Tanelin (2012) mukaan Hollon sivistyskasvatusajattelu korostaa mielikuvitusta ja estetiikkaa. Jokaisella ihmisellä tulee olla mahdollisuus saada kasvatuksen avulla laaja-alainen esteettis-eettinen, sivistyksellinen perusta itselleen, jonka puitteissa "ihmisen on mahdollista ihmistyä, tulla siksi, mitä hän pohjimmiltaan on" (Taneli, 2012, s. 241). Martti Hellströmin (2012) mukaan Hollo ajatteli, toisin kuin useimmat, että lapsuus ei ole ikäkausi, jossa mielikuvitus rehottaa, vaan nuoruus (ks. myös Taneli, 2012, s. 163). Tätä Hollo hänen mukaansa perusteli sillä, että mielikuvitus kehittyy iän lisääntyessä, ja mielikuvitusta voi kehittää, kun kasvatuksessa kiinnitetään huomiota tunteisiin. Hellström (2012) tulkitsee Hollon ajattelussa kasvattajan eräänlaiseksi fasilitaattoriksi, mahdollistajaksi, joka myös poistaa luonnollisen kasvuvoiman eteen nousevia esteitä. Hollolaisittain ajateltuna kasvattaja onnistuu kasvatuksessa, jos kasvavalla on itsellään halu kasvaa tuohon suuntaan.

Hollo itse kirjoittaa kasvattajan tehtävästä, roolista ja ominaisuuksista muun muassa Kasvatuksen teoria -teoksensa (1959) kuudennessa luvussa. Hollon käsitys kasvattajasta sisältää myös ajatuksen kasvamisesta. Hollon (1959, s. 77) mukaan "kasvattaja on myös kasvatettava", siten ei täydellinen tai valmis, sillä kaikki kasvatus edellyttää hänen mukaansa aina kasvamista (Hollo, 1959, s. 78). Tähän tarvitaan kasvattajan "sisäistä liikkuvuutta, jähmeyden ja äijämäisyyden vastakohtaa" Hollo luonnehtii jäykkää kasvattajaa hauskasti "peruukkimaiseksi" (Hollo, 1959, ss. 79-80). Hollo karsastaa ajatusta kasvattajasta vallanpitäjänä, sen sijaan hän korostaa kasvattajalla "suotavan olevan muovaus- 
ja leikki-iloa, taipumusta ja voimaa laajentaa omaa minuuden piiriä sekä kuvitteluelämän virkeyttä" (Hollo, 1959, ss. 81-82). Suorannan (1996) mukaan Hollo oli aikaansa edellä ainakin kahdessa suhteessa: Hollo ymmärsi kasvatuksen luonnollisena kasvamisvoimana, jonka tieltä tulee raivata esteitä sekä korosti kykyä nähdä kasvatuksellisesti.

Taidekasvatuksen alalla Marjo Räsänen (2010) soveltaa Hollon ajatuksia toteamalla, että hollolaiset kokonaisvaltaisuus, esteettisyys ja luovuus kuuluvat jokaiseen oppiaineeseen. Räsänen (2010, s. 351) toteaa seuraavaa:

Juho Hollo (1917) puhuu kasvatuksesta taiteeseen, taidetta varten ja taiteen avulla, ja hänen mukaansa opetusta tulisi kokonaisuudessaan lähestyä kasvatuksen taiteena. Kun taitavasta opetuksesta puhutaan Hollon ajatuksia mukaillen opetuksen taiteena, kannustetaan opettajaa suhtautumaan oppituntiin samalla intensiteetillä kuin taideteokseen. Perinteisestä, yksilökeskeisestä taidenäkemyksestä poiketen "opettajataiteilija" voi tukeutua nykytaiteeseen, jolle on ominaista taiteidenvälisyys ja todellisuuden tutkiminen eri tiedonalojen menetelmillä. Tällaiseen taidekäsitykseen tukeutuva oppimistapahtuma ei pohjaudu opettajan esitykseen, vaan muistuttaa enemmänkin yhteisötaidetta niin, että "oppimisteos" syntyy vuorovaikutuksessa oppilaiden kanssa.

Räsänen (2010) jatkaa ajatusta pohtimalla opetuksen taiteen kytkemistä myös luovuuden ja leikin käsitteisiin. Siinä hän näkee hollolaiseen tapaan tunteiden, aistimellisuuden ja huumorin merkityksen suurena. Räsäsen mukaan opetustilanteen ja -paikan voi ymmärtää improvisaatiolle ja yllätyksille avoimeksi ympäristöksi, ja havainnollistaminen ja elämyksellisyys ovat keskeisiä piirteitä opetuksen taiteessa. Edelleen Räsäsen (2010, ss. 351-352) mukaan opettajan tulisi luopua yksittäisten faktojen välittämisestä ja huomioida mielikuvituksen ja aistien rooli tiedon henkilökohtaisen merkityksen muodostumisessa. Hollo itse korosti kuvitteellisen tiedon kuuluvan "arvoa luoviin tekijöihin" (Hollo, 1952, s. 101).

Myös Veli-Matti Värri (2014, ss. 94-95) sanoo, että lasten kauneuden tajua tulisi ruokkia ja rohkaista, sillä kauneuden kokeminen kumpuaa alun perin lapsen aistimellis-kehollisesta suhteesta maailmaan. Kauneuden tajua tulisi ruokkia ja rohkaista hänen mukaansa erityisesti tietoisin pedagogisin keinoin. Juuri tästä syystä ihmisyys kasvatuksen ideaalisena päämääränä (hollolaisittain) on sisällöllisesti joustava, ja kukin aikakausi joutuu pohtimaan kasvatusihanteidensa sisällön uudelleen, joskin perinteitä kunnioittaen. Michael Uljensin (2007, s. 2) mukaan Hollon käsitys kasvatuksesta oli orgaaninen; käsitys muodostui filosofian, kielen ja kasvatuksen kokonaisuudesta. Taneli (2012, s. 38) luonnehtii siinä taustalla vaikuttavaa sivistysihannetta (uus)humanistiseksi. Uljensin (2007) mukaan Hollo näki kielen mielikuvituksen välttämättömänä, kulttuurisesti annettuna elementtinä ja kuvittelun oman ajattelun kasvuna. Keskeistä tässä on ihmisen oma kokemuksellisuus.

\section{Uudet varhaiskasvatussuunnitelman perusteet ja monilukutaito}

Oppimateriaaleihin ja -ympäristöihin liittyvä monipuolisuus, esteettisyys ja innostavuus kuuluvat suomalaiseen varhaiskasvatukseen: esimerkiksi Varhaiskasvatussuunnitelman perusteiden (Opetushallitus, 2018, s. 43) 
mukaan saatavilla olevat monipuoliset välineet ja materiaalit ovat merkityksellisiä erilaisiin ilmaisumuotoihin tutustuttaessa. Suomalaisen varhaiskasvatuksen yhtenä tavoitteena on "toteuttaa lapsen leikkiin, liikkumiseen, taiteisiin ja kulttuuriperintöön perustuvaa monipuolista pedagogista toimintaa ja mahdollistaa myönteiset oppimiskokemukset" (Opetushallitus, 2018, s. 15). Esteettisyys ja kokemuksellisuus nähdään myös tärkeänä lasten kulttuuri-identiteetin kannalta: "Lapsia tuetaan kulttuuriidentiteettien rakentamisessa. Varhaiskasvatuksessa saadut kokemukset, tiedot ja taidot kulttuuriperinnöstä vahvistavat lapsen kykyä omaksua, käyttää ja muuttaa kulttuuria" (Opetushallitus, 2018, s. 25). Ympäristö- ja luontokasvatuksesta todetaan, että tavoitteena on vahvistaa lasten luontosuhdetta ja vastuullista toimimista ympäristössä sekä ohjata heitä kohti kestävää elämäntapaa (Opetushallitus, 2018, s. 45). Tämä toteutuu kolmella tapaa: oppimisena ympäristössä, oppimisena ympäristöstä sekä ympäristön puolesta toimimisena. Siten luonto on varhaiskasvatuksessa sekä itsessään oppimispaikka että oppimisen kohde ja osaltaan kulttuurikasvatukseen liittyvä materiaalisen ja henkisen vuorovaikutuksen tila.

Suomalaisella varhaiskasvatuksella on pitkät perinteet ja se on sidoksissa yhteiskunnan ja kulttuurin kehitysvaiheisiin. Pohjoismaiseen hyvinvointivaltion varhaiskasvatukseen on vahvasti sisältynyt ajatus hoidon, kasvatuksen ja opetuksen eriytymättömistä ja toisiinsa kietoutuneista kokonaisuudesta, niin kutsutusta educare-mallista (mm. Alila ym., 2014). Suomalaista varhaiskasvatusta teoreettisesti ohjaava sosiokulttuurinen näkökulma oppimisesta (ks. esim. Kumpulainen, 2018) ei ole myöskään erillinen suhteessa kasvatukseen ja hoitoon; sosiokulttuurisesta näkökulmasta oppiminen merkitsee ennen kaikkea kulttuurisiin käytäntöihin osallistumista osana jonkin yhteisön toimintaan. Osallistumisessa oppiminen ja kehitysosaaminen syntyvät ja välittyvät toimijoiden vuorovaikutuksessa erilaisten perspektiivien kautta. Ihminen oppii hallitsemaan erityisesti niiden yhteisöjen ajattelun ja toiminnan välineitä, joihin hän osallistuu. Osallistumisen lisäksi sosiokulttuurinen oppimisen viitekehys korostaa välineiden merkitystä ihmisen toiminnassa ja kehityksessä (Säljö, 2001; Vygotsky, 1976).

Uusissa varhaiskasvatussuunnitelman perusteissa monilukutaito esiintyy osana laaja-alaisen osaamisen kokonaisuutta ja määritellään ajattelun taidoksi. Monilukutaidolla tarkoitetaan erilaisten viestien tulkitsemista ja tuottamista sekä ymmärtämistä (Opetushallitus, 2018). Varhaiskasvatussuunnitelman perusteissa määritelmä sivuaa New London Groupin (1996) ajatusta siitä, että yhä moninaistuvammassa maailmassa ihminen tarvitsee taitoja ymmärtää, tulkita ja tuottaa erilaisia tekstejä. Monilukutaito kytkeytyy myös vahvasti kulttuuriseen ymmärtämiseen sekä kulttuuriperinnön vaalimiseen ja siirtämiseen: monilukutaitoinen ihminen ymmärtää, että viestit ovat kulttuurisidonnaisia (Kumpulainen ym., 2018).

Monilukutaidon kehittäminen osana toiminnallista kulttuurikasvatusta integroituu luontevasti ja laajasti varhaiskasvatuksen oppimisen alueisiin. Lasten aktiivisuutta ja osallisuutta korostavaa pedagogiikka ja tutkiva oppiminen on lapsille luontaista (ks. Lipponen, 2016; Knif \& Kairavuori, 2018), joten varhaiskasvatuksessa myös kulttuurisiin sisältöihin on mielekästä tutustua käytännönläheisesti ja elämyksellisesti. 
Varhaiskasvatussuunnitelman perusteissa (Opetushallitus, 2018, s. 47) todetaan myös, kuinka "luonto voi olla myös esteettisen kokemisen ja rauhoittumisen paikka”. Käytännönläheisyys ja elämyksellisyys edustavat myös hollolaista kasvatusajattelua, jota tässä artikkelissa pohditaan suhteessa varhaiskasvatuksen opettajien erilaisiin Haltijan kuiskaus -materiaalin soveltamisiin.

\section{Haltijan kuiskaus -materiaali}

Kuten edellä todettu, tämän artikkelin kirjoittajat ovat olleet mukana laatimassa pedagogista materiaalia nimeltä Haltijan kuiskaus (Erfving ym., 2017). Juho Hollon kasvatusajattelu ei ole alun perin ollut materiaalin laatimista määrittävä viitekehys, mutta aineiston pedagogiseen käyttöön liittyvien tutkimustemme (Nordström ym., 2019; Sairanen ym., 2019) myötä aloimme aavistaa tällaisen implisiittisen yhteyden olemassaolon ja tämä aavistus kannusti meitä keskittyneeseen Hollo-luentaan.

Haltijan kuiskaus on verkossa avoimesti saatavilla oleva suomalaisia luontouskomuksia ja myyttejä käsittelevä digitaalinen pedagoginen materiaali. Julkaisimme materiaalin avoimesti ja digitaalisesti tukeaksemme kestävää kasvatus- ja opetuskulttuuria sekä varhaiskasvatuksen tavoitteita integroida monilukutaitoa ja digitaalista kulttuuria mielekkäällä tavalla. Tausta-ajatuksena on, että näiden uskomusten ja tarinoiden käsittely edistää lasten kulttuurista ymmärrystä sekä myös holistista luontokäsitystä (ks. Willamo, 2005, s. 170) ja toimii siten yhtenä varhaiskasvatuksen resurssina. Haltijan kuiskaus ei ole varsinainen oppikirja, vaan se on pedagogiselta luonteeltaan avoin materiaali. "Tehtävät tulevat ulos materiaalista", kuten yksi sen tekijöistä toteaa (Sintonen, 2017). Materiaaliin sisältyviin tehtäviin ei ole oikeita ratkaisuja, ja ylipäätään koko materiaalille ei ole yhtä oikeaa käyttötapaa. Haltijan kuiskauksen tuottamisessa on kiinnitetty erityistä huomioita materiaalin esteettisyyteen ja visuaalisuuteen; rauhallisuus, lempeys ja tarinallisuus sekä orgaanisuus ovat kehystäneet materiaalin suunnittelua (Sintonen, 2017). Esteettisyys on yksi tärkeä hollolainen arvo.

Haltijan kuiskauksen pedagoginen lähtökohta on monilukutaidon teoriassa. Monilukutaito määritellään New London Groupin (1996) mukaan laaja-alaisena tekstikäsityksenä. Tekstillä viitataan muun muassa sanalliseen, kuvalliseen, numeeriseen, auditiiviseen ja kinesteettiseen kommunikaation sekä näiden yhdistelmiin. Monilukutaito on tekstien merkitysjärjestelmien tulkintaa, purkamista ja rakentamista eri tavoin ja erilaisissa ympäristöissä. Se merkitsee taitoa hankkia, tulkita, käyttää, tuottaa, esittää ja arvioida tekstejä eri muodoissa, eri ympäristöissä ja tilanteissa sekä erilaisten välineiden avulla. Vaikka monilukutaito sisältää erilaisia lukemisen ja tekstin tuottamisen taitoja, sitä ei käsitetä yksinomaan kokoelmana erilaisia lukutaitoja. Sen sijaan monilukutaito nähdään rajapintoina, vuorovaikutusprosesseina ja sosiaalisina käytänteinä (Kumpulainen ym., 2018).

Haltijan kuiskaus -materiaalin pedagogisena tavoitteena on herättää ja laajentaa lasten omakohtaista kiinnostusta suomalaista luontoa ja vanhoja uskomuksia kohtaan, ja tämä antaa hyvän lähtökohdan osallistavalle ja toiminnalliselle kulttuurikasvatukselle. Tehtävät houkuttavat 
lapsia tarkkailemaan, pohtimaan, keksimään ja kokeilemaan. Materiaalikokonaisuus sisältää monipuolisin välinein ja tavoin toteutettavia tehtäviä, ja tehtäviin voi esimerkiksi liittää erilaisia digitaalisia sovelluksia. Haltijan kuiskauksen taustalta löytyy tekijöiden yhdessä jakama ajatus siitä, että materiaalilla pyritään innostamaan lapsia toimintaan, kuten omaan tarinointiin ja keksimiseen. Materiaalin tekijät puhuvat pedagogisesta suunnittelusta, jossa avoimuus ja sovellettavuus on sisäänkirjoitettuna (Sintonen, 2017). Tämä mahdollistaa materiaalin käytön erilaisissa oppimisympäristöissä ja sosiaalisissa tilanteissa, sillä varhaiskasvatusta on tarpeen toteuttaa ottaen huomioon myös lasten osallisuus ja heidän omat kiinnostuksenkohteensa. Huolellinen pedagoginen suunnittelu edesauttaa opettajien ja oppijoiden inspiroinnissa: materiaali tarjoaakin puitteet toiminnalle ja oppimiselle, joka ei perustu saman asian toistamiseen vaan ennemminkin uuden ja ennakoimattoman kohtaamiseen. Kuitenkin niin, että sisällöllä on tarttumapintaa olemassa olevaan eli tässä tapauksessa suomalaiseen luontoon, uskomuksiin ja kulttuuriin.

\section{Tutkimuskysymykset, aineisto ja menetelmät}

Tässä tutkimuksessa kysytään, millaisina varhaiskasvatuksen opettajat kuvaavat Haltijan kuiskaus -projektejaan ja miten nämä kuvaukset heijastelevat J. A. Hollon kasvatusajattelua. Tutkimus ei sinänsä ole analyysi Hollon kasvatusfilosofisista teksteistä, vaan olemme kiinnostuneita siitä, miten varhaiskasvatuksen pedagoginen toteuttaminen heijastelee erityisesti hollolaisia kasvatusajatuksia varhaiskasvatuksen opettajien toimiessa kulttuurikasvattajina sekä toteuttaessa varhaiskasvatussuunnitelman perusteita (Opetushallitus, 2018). Olemme tarkastelleet Hollon ajatuksia joidenkin hänen alkuperäistekstiensä lisäksi Holloon perehtyneiden nykytutkijoiden kirjoitusten valossa. Tutkimustiimillämme on myös ollut mahdollisuus keskustella J. A. Hollon ajattelusta syvällisesti aiheeseen perehtyneen tutkija Matti Tanelin kanssa Helsingissä elokuussa 2018. Samoin kokonaisluentaan on liitetty mukaan uudistetut Varhaiskasvatussuunnitelman perusteet eli VASU vuodelta 2016 (päivitetty versio 2018).

Tutkimuksen aineistona on neljän varhaiskasvatuksen opettajan kuvaamat Haltijan kuiskaus -projektit, niihin liittyvät materiaalit sekä opettajien haastattelut. Varhaiskasvatuksen opettajista kolme toimii pääkaupunkiseudulla ja yksi itäisessä Suomessa. Heistä kahdella oli Haltijan kuiskaus -projektin aikaan 6-vuotiaista lapsista koostuva esiopetusryhmä ja kahdella 5-vuotiaiden ryhmä. Aineisto kerättiin noudattaen hyvän tieteellisen etiikan periaatteita ja aineistoa on säilytetty, käsitelty ja siteerattu tutkittavien anonymiteetti säilyttäen ja Helsingin yliopiston tutkimuseettisiä ohjeita noudattaen.

Tässä laadullisessa tutkimuksessa tarkastelun kohteena olevat varhaiskasvatuksen opettajien suunnittelemat uniikit Haltijan kuiskaus -projektit on toteutettu syyslukukauden 2017 aikana ja opettajia on haastateltu joulukuun 2017 ja tammikuun 2018 aikana. Koska olimme erityisen kiinnostuneita varhaiskasvatuksen opettajien erilaisista pedagogisista ratkaisuista ja tavoista soveltaa suomalaisiin luontouskomuksiin ja myytteihin liittyvää Haltijan kuiskaus -materiaalia ja sitä kautta ymmärtää opettajien kulttuurikasvatusta, päädyimme aineistonkeruumenetelmänä 
haastatteluun. Haastatteluja voidaan luonnehtia asiantuntijahaastatteluiksi, sillä varhaiskasvatuksen opettajia pyydettiin kertomaan omin sanoin heidän toteuttamistaan Haltijan kuiskaus -projekteistaan sekä niiden pedagogisista perusteista ja suhteesta Varhaiskasvatussuunnitelman perusteisiin. Haastatteluista, joissa varhaiskasvatuksen opettajia pyydettiin kertomaan projekteistaan, yksi toteutettiin etänä (verkkopuhelu ja haastateltavan itse tekemä tallenne) ja kolme paikan päällä päiväkodissa. Kaksi tallennettiin videona ja kaksi audiona, ja aineisto litteroitiin. Varhaiskasvattajien työpaikoilla toteutetut haastattelut antoivat myös tutkijoille mahdollisuuden tutustua lasten työstämiin Haltijan kuiskaus -teoksiin, käytettyihin materiaaleihin, laitteisiin sekä oppimisympäristöihin (sisällä ja ulkona).

Ensimmäinen tapaus (vo1) on lähes koko syyslukukauden kestänyt prosessi, joka kasvoi ja kehittyi tarinallisesti ja toiminnallisesti lasten aloitteista. Kyseessä on monikulttuurinen 5-vuotiaiden ryhmä. Projektiin ei sisältynyt juurikaan digitaalisia laitteita tai sisältöjä, vaan sen moniin vaiheisiin sisältyi paljon lasten omaa suunnittelua sekä käsillä tekemistä ja askartelua. Projekti piti sisällään myös lasten aloitteesta syntyneen keijujen lentokoulun ja pokemonjahtia metsässä.

Toinen (vo2) Haltijan kuiskaus -projekti perustui lasten digitaaliseen sisällöntuottamiseen (erityisesti oma tarinankerronta), sillä projektissa lapsia kannustettiin kuvaamaan luonnosta löytyviä kohteita (kuten kiviä ja oksia) ja esimerkiksi kertomaan tarinoita "niiden suulla" digitaalista tekniikkaa monipuolisesti hyödyntäen. Kyseessä oli esikouluryhmä. Koko syyslukukauden kestäneessä projektissa lasten tuotokset koottiin digitaaliseen kollaasiin, johon sisältyi myös varhaiskasvatuksen opettajan itse tuottamaa ja Haltijan kuiskaus -materiaalista soveltamaa sisältöä.

Kolmas (vo3) Haltijan kuiskaus -toteutus sisälsi monia osaprojekteja pitkin lukuvuotta, joissa sovellettiin erilaisia materiaalia ja digitaalisia välineitä yhdessä eri ikäisten oppijoiden kanssa. Projekteissa esimerkiksi kolmasluokkalaiset oppilaat tekivät digitaalisia tarinoita ja mobiilisarjakuvia yhdessä esikouluikäisten kanssa. Näissä projekteissa samoin digitaalista sisältöä tuotettiin ulkona luonnosta löytyvien paikkojen ja materiaalien avulla.

Neljännessä (vo4) Haltijan kuiskaus -projektissa monikulttuurisessa 5-vuotiaiden ryhmässä lapset saivat suunnitella ja toteuttaa pienryhmissä digitaaliset animaatiot pohjautuen materiaaliin. Ryhmän varhaiskasvatuksen opettaja innostui hyödyntämään materiaalia ja rohkaistui ottamaan mukaan toimintaan lasten digitaalista sisällöntuottamista. Projekti kesti noin kolme kuukautta, jossa hyödynnettiin metsäpedagogiikka, tarinallisuutta, mediakasvatusta ja taidekasvatusta.

Haastatteluaineistoa lähestyttiin induktiivisesti (mm. Patton, 2002), koska kyseessä on neljä erilaista pedagogista prosessia, joita ei sinänsä asetettu vertailuasemaan, vaan niistä etsittiin yhteisiä temaattisia piirteitä Hollon kasvatusajattelun luentana, koska tavoitteenamme oli tarkastella, millaisina varhaiskasvatuksen opettajat kuvaavat Haltijan kuiskaus -projektejaan ja miten nämä kuvaukset heijastelevat J. A. Hollon kasvatusajattelua. Temaattisten piirteiden tavoittelulla tähtäämme selittämisen sijaan ilmiön kuvailuun ja pedagogisen potentiaalin esittämiseen. Analyysissä noudatimme kuusivaiheista teemoittelua Braunin ja Clarken (2006) 
mukaan: 1) aineistoon tutustuminen, 2) alustava teemoittelu (raakakoodaus), 3) teemojen etsiminen, 4) teemojen tarkastelu ja muokkaaminen, 5) teemojen nimeäminen ja 6) raportointi. Aineisto on tuttu kaikille tämän artikkelin kirjoittajille: teemoittelun ja teemojen nimeämisen toteutti artikkelin ensimmäinen kirjoittaja ja kaikki kirjoittajat ovat osallistuneet havaintojen ja muodostettujen teemojen reflektointiin ja artikkelin kirjoittamiseen. Seuraavassa kuvaamme analyysimme tuloksia aineistosta esiin nousseiden viiden teeman valossa: elämys ja materiaalin henki, tarinat ja tarinallisuus, leikki ja mielikuvittelu, innostuminen ja heittäytyminen sekä osallisuus. Seuraavaksi siirrymme tarkastelemaan näitä hollolaisen kasvatusajattelun hengessä.

\section{Tulokset: Heijastumia hollolaisesta kasvatus- ajattelusta}

Olemme löytäneet varhaiskasvatuksen opettajien pedagogisessa työssä ja valinnoissa heijastumia ja yhtymäkohtia hollolaiseen kasvatusajatteluun ja tarkastelemme niitä ymmärtäen, että puhdasta ja aukotonta tulkintaa ei voida saavuttaa. Tapauskohtainen analyysimme ei välttämättä tee oikeutta Hollon laajalle näkemykselle ja hänen viljeltyneelle maailmankuvalleen. Silti on todella mielenkiintoista pohtia ja tarkastella Hollon kasvatusajattelua lähes satavuotisena puheenpolkuna; millaisia jälkiä sillä on ajassamme ja todennäköisesti tästä eteenpäinkin. Myös erityisesti varhaiskasvatuksen tutkimuksen kannalta on tärkeää "avata historiallisia horisontteja" (Onnismaa \& Paananen, 2019, s. 214) ja nostaa esiin toisiakin ääniä.

\section{Elämys ja materiaalin henki: kokemuksia metsässä}

Kaikki varhaiskasvatuksen opettajat (vo) olivat toteuttaneet Haltijan kuiskaus -projektejaan osin ulkona ja metsässä. Metsämaasto on löytynyt oman päiväkodin tai koulun välittömästä yhteydestä. Hollolaiseen sivistyskasvatusajatteluun kuuluvat elämykset ja esimerkiksi oppisisällöt on tehtävä elämyksellisesti koettaviksi (Taneli, 2012, ss. 149, 263; Taneli, 2012, s. 160 Wileniukseen (2002) viitaten). Hollo liitti elämysajatukseen käsitykset tunteista ja kuvittelusta, antaen kuitenkin elämykselle itseisarvon todellisuuden kokemisen syventäjänä (Taneli, 2012, s. 180). Aineistostamme nousee esiin "metsään meneminen" pedagogisena ratkaisuna, keinona aistia ja kokea luontoympäristöä. Varhaiskasvatussuunnitelman perusteissa (Opetushallitus, 2018, s. 32) todetaan, että oppimisympäristöjä suunnitellaan myös yhdessä lasten kanssa ja lapsille tulee olla mahdollisuus tutkia maailmaa kaikilla aisteillaan ja koko kehollaan. Aineistostamme teema nousee esiin sekä "lasten viemisenä metsään [aikuisten toimesta]" että lasten omana aloitteena metsään menemisestä.

vol: Eli, ensin me mentiin metsään. Me vietiin sinne vesivärit, pensselit ja paperit et lapset sai maalata mättäällä istuen.

vo3: Nimittäin päätettiin se et viedään ne lapset metsään, kolmasluokkalaiset, ja eskarit ja muodostetaan semmosta vähän niinku leikinomaista asiaa ja otetaan kuvia ja käsitellään niitä tietyn laisilla sovelluksilla, niin siinä tilanteessa ku tätä ensimmäistä 
Ainedidaktiikka 4(2) (2020)

kertaa lapsille esiteltiin nii siellä oli siis yks kokonainen kolmosluokka ja eskarit ja opettaja joka oli keränny materiaalia tästä kansanperinteestä, niin käytettiin niit sovelluksia millä sitten jatkokäsitellään niitä kuvia mitä he ottaa ja niitä elokuvia mitä he tekevät siellä metsässä

\section{T: Okei, nii muistatsä miten lapset suhtautu tähän}

vo: Ne oli aika aktiivisia

vo4: Ne pyys hirveesti lisää ja ne halus tehä enemmänki ja sit ne oli hirveesti aina menossa uudestaan metsään ja sit ne bongaili niitä haltijoita joka paikassa,

Haltijan kuiskaus -projektien metsäosuuksia käsiteltiin ryhmissä jälkeenpäin yhdessä keskustellen ja reflektoiden.

vo1: Ja sit lapset sai valita emojin joka kuvastaa milt tuntuu olla metsässä. Joku rakasti metsäs olemist. Jonku mielest se oli kivaa, jonku mielest se oli todella ärsyttävää koska puunoksat heiluu ja häiritsee.

Varhaiskasvatuksen opettajat mainitsevat myös materiaalin hengen. Kulttuuriin liittyvänä ilmaisuna henki on Lauri Rauhalan (2009, ss. 62-63) mukaan arvottava laatumääre, eikä esimerkiksi jokin näkymätön energia tai aineeton olento. Henkeä hänen mukaansa on jokin hyvä, kaunis ja oikea, joihin myös yhteisiä aatteita ja ihanteita suunnataan. Liitämme asian tässä yhteydessä aikuisten ja lasten yhteisesti koettuun ja tunnettuun elämykseen, ja myös innostumiseen ja heittäytymiseen.

vo4: Se materiaalin henki on ollu tässä niinkun läsnä koko ajan.

Elämys suhteessa kasvatukseen on kiinnostava näkökulma. Jukka Sihvonen (1996, s. 31) on pohtinut elämystä merkitysten muodostumisen kautta ja toteaa, että merkitys ei muotoudu puhtaasti ajattelun tasolla vaan siinä, miten merkitys "havaituksi tullessaan liikuttaa ja määrittelee havaitsevaa subjektia, miten se resonoi minussa". Tanelin (2012, s. 152) mukaan Hollo ajatteli samoin todetessaan, että esimerkiksi taideteoksen tulkinta on haettava teoksesta "sellaisena kuin se lukijalle tarjoutuu". Aineistomme perusteella varhaiskasvatuksen opettajat eivät korosta lasten tekemisissä lopputuotoksia, vaan prosessia myös yhteisenä elämyksiä tuottavana kokemuksena.

\section{Tarinat ja tarinallisuus: puhuva kallio ja muita juttuja}

Varhaiskasvatussuunnitelman perusteissa (Opetushallitus, 2018, s. 49) korostetaan rikasta ja vaihtelevaa kieli- ja tekstimaailmaa, ja sen mukaan lapsia tulee myös kannustaa keksimään omia tarinoitaan. Puheen rinnalla suositellaan käytettäväksi myös visuaalisia, auditiivisia ja audiovisuaalisia tekstejä, jonka voi havaita myös tutkimukseen osallistuvien varhaiskasvatuksen opettajien kuvauksissa. Hollon aikana ei ollut tarjolla yhtä laajoja ja monimodaalisia tekstejä, mutta esimerkiksi opetuskäyttöön tarkoitettuja kuvatauluja kylläkin. Niitä Hollo on Tanelin (2012, s. 157) mukaan pitänyt kuolleina kuvina, joiden sisältöä tulee elävöittää taitavalla sanojen käytöllä. Lawrence ja Paigen (2016, s. 66) mukaan tarinat voivat inspiroida, herättää tunteita ja tukea lapsen oppimista, ja erityisesti menneisyyden myytit ovat oivallinen tapa myös oppia ymmärtämään, mikä merkitys 
Ainedidaktiikka 4(2) (2020)

yhteisesti jaetuilla tarinoilla ja myyttien synnyllä on ollut kulttuurin kehittymisen ja ihmisten elämän näkökulmasta. Jerome Bruner $(1986 ; 1990)$ selittää narratiivisen ajattelun perustuvan synnynnäisille kyvyille, joita kulttuuri kertomisen ja tulkitsemisen perinteillä kehittää. Lapsella näitä kykyjä ovat muun muassa kiinnostus inhimilliseen vuorovaikutukseen, tapahtumien organisointi peräkkäisiksi rakenteiksi, tapahtumiin liitetyt tunteet ja kyky kohdistaa huomio yllätykselliseen.

vo4: Vähä alettiin tiimissäkin miettimään että, että tota nää kaks aihetta, tän haltijan kuiskauksen ja animaation vois yhdistää ja sit haluttiin sitä tarinankerrontaa siihen niinku myös, myös mukaan.

vo3: Sit nämä huoneet sijotettiin täällä koululla sarjakuva-sovellukseen johon laitettiin puhekuplilla vähän sitä ideaa että mitä se haltija, miksi se oli haltijalle tärkeä huone tai mitä, mitä se tykkäs keittiös se söi ehkä jotain lehtikeittoa tai, tai tykkäsi sienisopasta et se tavallaan tuli näkyväks myös niille muille et mikä siinä huoneessa oli tavallaan se haltijan kannalta tärkee juttu.

Varhaiskasvatussuunnitelman perusteet (Opetushallitus, 2018, s. 42) nostavat esiin myös lasten kyvyn kuvitella ja luoda mielikuvia, ja perusteissa kehotetaan dokumentoimaan lasten kertomuksia.

vo2: Ja nyt aikuiset sit totes että se ei ihan sillä tavalla lähteny ku he ajatteli että siellä tulis niinku suomalais.. et suomalais kansansadut kiinnostais tai välttämättä se jotkut metsään liittyvät asiat mikä oli aikuisten idea, mut tota se että täs oli se tarinankerronta se tärkein juttu nii se lähti niinku elämään. Ja pohjalla oli nyt nämä haltijan.. niinku aikuisten opettajien ... pohjamateriaalina oli tää haltijankuiskausmateriaali. Senkin tosin näytin lapsille että on olemassa tällänen niinku tehtävä et sen takia siinä oli sekin kuvaa siitä tehtävästä. Et se oli sellanen tilanne.

Myös aikuisten oma suhtautuminen ja pedagoginen toiminta vaikuttaa tilanteissa, ja aikuiset myös antavat esimerkkiä omalla toiminnallaan, toimivat hollolaisittain esikuvallisesti. Hollon (1959, s. 94) teksteistä sopii tässä yhteydessä nostaa esiin myös ajatus kasvatuksellisesta kosketuksesta. Hollo (1959, s. 98) kirjoittaa: "Olemme edellä nähneet, että kaikkein tärkeimpiä edellytyksiä on opettajan ja kasvattajan alinomainen voimakas eläytyminen niihin sisältöihin, joihin heidän toimintansa kulloinkin kohdistuu." Hollo kehotti miettimään, miten välttää kasvatustehtävän muuttumista opetustehtäväksi (1959, s. 99).

vo2: Alkuun katsottiinkin niitä muita kuvia, mut sitte, siin loppuvaiheessa näytin sen, sen sen motivointivideon siitä puhuvasta kalliosta. Ja sehän olikin sitte kovin niinku innostava juttu. Ja tota, sitten, sit sanoin, annoin niinku tehtäväks lapsille että nyt te saatte kertoo että, nyt saatte parin kanssa miettiä et mitähän se kallio kertoisi. Et ihan... minkälaisen tarinan se sinulle tai meille kertoisi ja saatte lähteä parin kanssa yhdessä piirtämällä suunnittelemaan sitä tarinaa ja sitte tehään, saatte tehä tämmösen oman videon. Ja tota, sehän oli hyvin innostavaa.

vo2: He jatkoivat näitä metsäretkiä, ja kuulemma jokaisella kerralla siinä kallion kohdalla piti sitten pysähtyä kuuntelemaan että mitä se 
Ainedidaktiikka 4(2) (2020)

kallio kertoo. Ja se ei välttämättä, se ei tietenkään kertonu siinä hetkessä heille mitään mutt että sitte heille tuli semmonen käytäntö, että heillä oli semmoset omat pienet tarinavihkot, joihin tota sitte piti kirjotella niitä tarinoita aina sillo ku niitä synty, että niitä voi syntyä milloin vaa.

\section{Lasten leikki, mielikuvittelu ja niiden tukeminen: mielikuvitus- rikkautta}

Luova leikki ja keksiminen, oman mielikuvittelun käyttö on oleellinen lapsen kasvun ja kehityksen kannalta (ks. esim. Vygotsky, 1976; Bergen, 2002; Garvey, 1993). Leikillä on oma roolinsa myös kielen kehittymisen ja (kirjoitetun tekstin) lukutaidon oppimisen taustalla, varsinkin, kun puhutaan tarinallisesta ja mielikuvitusleikeistä.

vo3: En ehkä oo mitään haltijan leikkejä leikkiny, mut ne rakentelee tosi paljon.

vo1: Sit meil oli kartta, et lapset löys sen haltijan kannon ja se kutsu meidät tupaantulijaisiin

Varhaiskasvatussuunnitelman perusteissa todetaan, että "ihmettelylle, oivaltamiselle sekä oppimisen ilolle tulee olla tilaa" (Opetushallitus, 2018, s. 24). Tämän tutkimuksen perusteella varhaiskasvatuksessa yhteinen ihmettely ja oivaltaminen perustuvat lasten ja aikuisten väliseen vuorovaikutukseen. Hollo (1959, s. 112) kannatti samansuuntaista jaettua ihmettelyä ja siitä juontuvaa iloa. Hän korosti tässä sekä kasvattajan että kasvatettavan kuvitteellista mielen asennetta.

vo3: No esimerkiks puunrungoista saatto löytyä semmosia silmiä ja suita ja tota ihan siis semmosista paikoista mis oli kiviä ja kantoja ja mitä nyt voit kuvitella et metsästä löytyy.

vo2: Ja tota lähettiin sitte läheiseen metsään ja matkalla oli semmonen kallios leikkaus, johon opettaja kiinnitti lasten huomiota ja sitä jäätiin tutkimaan ja lapset, lasten mielestä siinä kalliossa näytti olevan kasvot tai useitakin kasvoja.

vo3: Ne sai ite valita ryhmässä, taas oli kolmasluokkalaisia ja eskareita yhessä ja he yhdessä päättivät et minkälaisia huoneita haltijan kodissa on. Ja se oli kyllä oikeesti tosi huippua koska siinä tavallaan se lapsen, lasten niinku yhteinen mielikuvitus pääs rakentumaan ja siellä oli, oli polttopuuvarastoja ja oli tota uima-altaita ja tehty jää uima-altaita ja ne perustelut et miksi se haltija viihty tietyis huoneis, nii oli aika semmosia mielikuvitusrikkaita et sillä saatto olla joku, haltija tykkää kylmistä huoneista eli hän nukkuu jäähuoneessa ja tota tavallaan se lähti hirveen hyvin lentämään et sillo ku digitaalista välinettä voidaan sijoittaa lapsen leikkiin tai lasten leikkiin ja kun se voidaan tehdä ryhmätyössä nii sillo tavallaan sil on..se on niinku oikealla paikalla .

Mielikuvittelun tukeminen on hollolaisen sivistyskasvatusajattelun ydintä, ja se liittyy Hollolla kiinteästi tunteisiin, joihin sillä on läheinen yhteys (ks. Taneli, 2012, ss. 143-145). Haltijan kuiskaus -materiaalin avoimuus ja sovellettavuus sekä varhaiskasvatuksen opettajien aito innostus ovat 
Ainedidaktiikka 4(2) (2020)

todennäköisesti tekijöitä, jotka ovat edistäneet tähän tutkimukseen liittyvien projektien mielikuvituksellista rikkautta niin toteutuksen kuin sisällön näkökulmista.

\section{Innostuminen ja heittäytyminen: roolileikkejä}

Suomalaiselle varhaiskasvatukselle on ominaista lasten toimijuuden tukeminen ja lapsilähtöisyys, jolloin kasvattajan ja kasvatettavien välistä suhdetta ei määritellä valtasuhteena. Taneli (2012, s. 256) pohtii: 'Itse ajattelen niin, että suoranainen opettaminen on oikeastaan mahdotonta. Opettaja-kasvattaja voi käsitellä aihettaan, käydä sen kimppuun ja käännellä sitä eri tavoin. Hänen on tärkeää heittäytyä käsiteltävän substanssin prosessointiin täysin sydämin oppilaiden edessä. Hänen on välttämätöntä saada aito yhteys opiskelijoihin.” Tutkimukseemme osallistuneilla varhaiskasvatuksen opettajille ei vaikuta olevan mitään estettä täysin sydämin haltijamaailmoihin heittäytymisissä.

vol: [...] hirveen niinku halu tehä tätä työtä. Niinku tavallaan niinku antaa lapsille mahdollisuuksii oivaltaa elämyksellisesti.

vo2: Seuraavana päivänä oli sitten tarkotus nyt tehä tarinoita metsäaiheeseen liittyen ja, ja ja oli se ajatus että niistä, jos sieltä olis niistä kuvistakin jotain mitä siinä retkellä oli ollu, nii saanu aikaseks, mutta sitä silmällä pitäen minä mietinkin sitte ja tein, tein siitä kallion kasvoista, nii semmosen, motivointivideon,

vo3: Ku oli monenlaisia projekteja, mutt ehkä semmonen yks ehkä mieleenpainuvimmista oli se, että ku tehtiin kolmasluokkalaisten, meil on kaks kummiluokkaa tänä vuonna, meijän eskareilla, ja toisen kummiluokan kanssa ku se esiteltiin se materiaali niin kolmasluokan opettaja oli pukeutunut haltijaksi.

Kun opettajan omasta toiminnasta huokuu innostus asiaan, tarttuu se usein lapsiinkin. Tutkimusten perusteella tiedetään, kuinka positiiviset tunnetilat, kuten ilo ja innostus, ruokkivat lasten ideointikykyä ja luovuutta (mm. Pekrun, Elliot \& Maier, 2006) ja toisaalta ovat yhteydessä lasten kokemukseen omaan oppimisympäristöön liittyvästä vaikuttamisesta ja osallisuudesta (ks. Kangas, 2010; Kumpulainen, Lipponen ym., 2014; Kumpulainen, Mikkola ym., 2014). Tutkimukseemme osallistuneet varhaiskasvatuksen opettajat ovatkin antaneet taitavasti tilaa myös lasten omille heittäytymisille.

vol: Sitten, sit me otettiin se haltijankuiskaus ja mä rupesin puhuu meijän viskareille metsänhaltijasta ja pelkäsin vähän et miten tää nyt lähtee käyntiin koska mul on erityislapsii, mulla on kielenkehityksen erityisvaikeuslapsii, paljon S2 lapsii, jotka opettelee suomenkieltä. Mut se läks ihan flowhun.

vo3: Nii ja tota täytyy sanoa se niinku että eri ikäisten lasten yhteistyö toimi tosi hienosti, koska tää oli myöskin vähän niinku leikki, et ne saivat paneutuu siihen omatahtisesti siihen rakenteluun ja neuvotteluun mitä sillä haltijalla oli ja miten se liikku. 


\section{Osallisuus: elementtejä lasten omista ajatuksista}

Osallisuus on yksi uuden Varhaiskasvatussuunnitelman perusteiden kantava tausta-ajatus. Varhaiskasvatuksen toimijoita kehotetaan osallisuutta edistävien toimintatapojen ja rakenteiden kehittämiseen (Opetushallitus, 2018, s. 30). Osallisuuteen kuuluu myös lasten yhteisöön, vastuuseen ja valintojen seuraamuksiin liittyvän ymmärryksen kehittymisen tukeminen (Opetushallitus, 2018, s. 30). Lasten mielikuvituksen tuottamaa työstetään yhdessä (Opetushallitus, 2018, s. 43). Hollo ei puhu samalla tavalla suoraan osallisuudesta kasvatuksessa, mutta hänen ajatustaan kasvatustapahtumasta jatkuvana vuorovaikutuksena voidaan lähtökohdiltaan pitää hyvin osallistavana. Tanelin (2012, s. 53) mukaan Hollo ennakoi nimenomaa muuttuvan kulttuurin vaatimuksia pitäessään kasvattajaa, kasvatettavaa ja niiden funktiota jatkuvassa vuorovaikutuksessa olevana kokonaisuutena; Hollo myös korostaa kasvatettavan omaa osuutta nimenomaan älyllisellä, mielikuvituksen elämänalueella.

vo4: Must oli kivaa, että sieltä niinku lasten omista ajatuksista tuli niitä elementtejä paljon, nii olisin myös voinu vielä enemmän niinku tuoda lapsia siihen tähän haltijamaailmaan ja myyttien maailmaan, jotta myös sieltä suunnasta olisi tullu enemmän elementtejä.

vo4: Esimerkiks vaik me ensin luettiin vähän kirjallisuutta ja sen jälkeen lapset sai sitte käydä muovailemaan niitä, niin mä en kuitenkaan niinku sit käyny ohjailemaan sitä muovailua hirveesti, vaan lapset sai niinku just tehdä niitä merirosvohaltijoitaan ja Dustylentokonehaltijoitaan, kun ne oli siitä aiheesta kiinnostuneita. Että tavallaan jos ois halunnu enemmän keskittyä siihen mytologiaan ja luontoon nii sithä ois voinu niinku enemmän ohjata myös sitä lasten työskentelyä siihen suuntaan.

vo1: Sit me kerättiin kepuloita ja lapset sano et jos sil on kattokruunu sil pitää olla verhot.

Erityisen kiinnostavaa on havaita, että ajalle ominaisten digitaalisten välineiden kautta varhaiskasvatuksen opettajat kokevat tukevansa lasten osallisuutta ja toimijuutta.

vo3: Ja tota mä haluan näyttää sen, mä haluaisin sillä mun toiminnalla antaa lapsille semmosen pääoman, et he voi toimia tuottajina ja suunnittelijoina ja arvioijina, ja tavallaan et se tabletti tulis johonki sellaseen käyttöön, joka ei oo pelkästään pelimaailman käyttö̈. Vaan et he toimis ylpeästi myös niinkun digimateriaalin tuottajana ja sen suunnittelijana ja tavallaan siihen tällänen mate-riaali kun Haltijan kuiskaus on hirveen hyvä, koska tää antaa lapsille sen mielikuvituksen, et se mielikuvitus tavallaan pystyy täyttämään sitä. Tää ei oo valmis materiaali sellasenaan tai mut tääl on kuitenki ohjaavat kysymykset siihen että et päästään tekemään lasten kanssa niitä tuotoksia ja näyttämään, et se digilaite toimii ihan muunlaisena välineenä - et meillä lapset ei oikeestaan kysy että saako pelata koska me täytetään tavallaan se, se tarve, toisenlaisella toiminnalla. 


\section{Lopuksi}

Olemme tässä artikkelissa tarkastelleet, kuinka varhaiskasvatuksen opettajat ovat eri tavoin soveltaneet suomalaisiin luontouskomuksiin ja myytteihin keskittyvää Haltijan kuiskaus -materiaalia omassa pedagogisessa työssään. Tarkastelussamme olemme erityisesti keskittyneet pohtimaan ja kuulostelemaan opettajien kertomaa joiltain osin suhteessa Juho Hollon kasvatusajatteluun. Hollolainen kasvatusajattelu, jota Taneli (2012) kutsuu sivistyskasvatukseksi, korostaa muun muassa hyvää elämää vahvistavaa, positiivista sekä kuuntelevaa ja kunnioittavaa vuorovaikutusta kasvattajan ja kasvatettavien välillä. Kasvatuksellinen näkeminen tunnistaa kasvatettavissa halun kasvuun ja pyrkii vahvistamaan sitä. Ihmistyminen on mahdollista toisia kunnioittavassa, tunteet, arvot ja historian huomioon ottavassa vuorovaikutuksessa, jonka perusta on mielikuvittelussa, ilossa, huumorissa ja aistimellisuudessa. On kiehtovaa havaita, kuinka Juho Hollon kasvatusajattelu voi kantaa yli kasvattajasukupolvien. Ymmärrämme, että Holloa ei tule lukea ja soveltaa riippumattomana ajattelijana, kuten Harni ja Saari (2016, s. 30) toteavat. Heidän mukaansa Hollon itsensä pyrkimys kuitenkin oli ajatella näkemys kasvatuksesta kasvamaan saattamisena ja näkemys kasvatuksen omalakisuudesta välineettömäksi, politiikasta vapaaksi elämänalueeksi.

Artikkelissamme esiin nousseet, varhaiskasvatukseen liittämämme teemat elämys ja materiaalin henki, tarinat ja tarinallisuus, leikki ja mielikuvittelu, innostuminen ja heittäytyminen, sekä osallisuus henkivät vahvasti hollolaista kasvatusta. Hollon ajatteluun perehtyneen Tanelin (2012, s. 35) mukaan kasvatuksessa tulee vaalia myös kasvatettavan omaehtoisuutta ja luovuutta. Tämän valossa suomalainen varhaiskasvatus näyttäytyy humanistisena, joka tavoittelee kasvatettavissa hyvää. Samoin ihmisen suhde luontoon näyttäytyy eettisenä ja esteettisenä hyvän elämän kokemusalueena. Tanelin (2012, s. 158) ajatuksia myötäillen voimme todeta, että monille opettajille ja heidän pedagogisille tavoilleen soveltaa Haltijan kuiskaus -materiaalia tärkeintä ei ollut se, "että jotakin on nähty, kuultu tai maistettu, vaan miten havaintokokemus on psyykkisesti eletty ja onko sitä ylipäätään lainkaan eletty vai ovatko havaintovaikutelmat vain ohimennen koskettaneet aistinelimiä."

Hollolaisen kasvatusajattelun mukaan kasvattaja on esteiden poistaja ja mahdollistaja; Tanelin $(2012$, s. 32) sanoin: "Ihmistä ei tule kasvattaa koskaan pelkästään työntekijäksi, vaan ihmiseksi, jolla on oma tahto ja tunteet ja jonka elämää leimaavat toivon elementti ja usko parempaan tulevaisuuteen." Tämä luo perustaa kestävälle ihmisen, luonnon ja kulttuurin kasvatukselliselle kokonaisuudelle (Laine, 2013). Myös Varhaiskasvatussuunnitelman perusteissa korostetaan vastuullista suhtautumista luontoon ja ympäristöön (Opetushallitus, 2018, s. 32). Näin ollen varhaiskasvatukseen liittyvä kulttuurikasvatus ei voi olla ajattelua ja toimintaa kangistavaa tai kahlitsevaa. Tähän tarvitaan kasvattajan joustoa, myös sisäistä joustoa eli avointa, ennakkoluulotonta asennetta ja kykyä improvisoida. Hollolaisuutta ja hollomaisuutta ovat myös leikki-ilo ja kuvittelun vireys. Kaikki nämä periaatteet ja arvot heijastuivat myös niissä pyrkimyksissä, joita varhaiskasvatuksen opettajat tässä tutkimuksessa kuvasivat pedagogisen toimintansa lähtökohtina. 
Haluamme lopuksi korostaa työmme tulkinnallisuutta liittyen Hollon kasvatusajatteluun. Kuten Juha Suoranta (1996) on todennut, jokainen tutkijasukupolvi löytää klassikkonsa uudelleen, lukee ne uusin silmin ja tekee tekstin näköisekseen omissa tulkinnoissaan. Hänen mukaansa yhtä yksiselitteistä Hollo-tulkintaa ei ole, sillä uusissa yhteyksissä tekstit saavat aina uuden elämän. Kirjoituksemme yhtyy näihin ajatuksiin nostamalla esiin hollolaista kasvatusajattelua varhaiskasvatuksessa kohteenaan erityisesti suomalaiset luontouskomukset ja -myytit. Ymmärrämme, että olemme onnistuneet vain raapaisemaan Hollon näkemyksiä suhteessa varhaiskasvatukseen ja tunnistamme tarpeen jatkotutkimuksille.

Työmme rajoituksista huolimatta toivomme, että esittämämme analyysit ja niistä johdetut tulkinnat rikastavat kulttuurikasvatuksen ymmärtämistä osana varhaiskasvatusta ja siihen liittyvää kasvatusajattelua. Samanaikaisesti tuomme työllämme esiin Haltijan kuiskauksen kaltaisten avointen sekä visuaalisesti ja sisällöllisesti kiehtovien materiaalien merkityksen erityisesti luontoon liittyviin uskomusten ja myyttien käsittelemisessä varhaiskasvatuksessa. Kenties tämä samalla viitoittaa kaikkia meitä uuteen, tulevaan ja ehkä ei niin tuntemattomaan.

\section{Lähteet}

Alila, K., Eskelinen, M., Estola, E., Kahiluoto, T., Kinos, J., Pekuri, H-M., Polvinen, M., Laaksonen R. \& Lamberg, K. (2014). Varhaiskasvatuksen historia, nykytila ja kehittämisen suuntalinjat. Opetus- ja kulttuuriministeriön työryhmämuistioita ja selvityksiä 2014:12. Helsinki: Opetus-ja kulttuuriministeriö.

Bergen, D. (2002). The role of pretend play in children's cognitive development. Early Childhood Research and Practice, 4(1), 1-12.

Braun, V. \& Clarke, V. (2006). Using thematic analysis in psychology. Qualitative Research in Psychology, 3(2), 77-101. https://doi.org/10.1191/1478088706qp063oa

Bruner, J. (1986). Actual Minds, Possible Worlds. Cambridge: Harvard University Press.

Bruner, J. (1990). The Act of Meaning. Cambridge: Harvard University Press.

Erfving, E., Hintsa, A., Sintonen, S., Sairanen, H. \& Kumpulainen, K. (2017). Haltijan kuiskaus. Helsingin yliopisto. http://hdl.handle.net/10138/206657

Garvey, C. (1993). Play. Cambridge, MA: Harvard University Press.

Harni, E. \& Saari, A. (2016). Elämän politiikka J. A. Hollon ajattelussa. Kasvatus \& Aika, 10(2), 19-32. https://journal.fi/kasvatusjaaika/article/view/68615

Hellström, M. (2012). Kesäretki kasvatustieteen historiaan. Osa 10: Juho Hollo. http://pedagogiikkaa.blogspot.com/2012/07/kesaretki-kasvatustieteen-historiaan 18. html

Hollo, J.A. (1932). Mielikuvitus ja sen kasvattaminen. Toinen painos. Helsinki: WSOY.

Hollo, J. A. (1952). Kasvatuksen maailma. Kokonaan uusittu laitos. Porvoo: WSOY.

Hollo, J.A. (1959). Kasvatuksen teoria: johdantoa yleiseen kasvatusoppiin. Viides painos. Porvoo: WSOY.

Ikonen, R. (2000). Mitä on se 'kasvatus'? Kasvatus, 31(2), 118-129.

Kangas, K. \& Rusanen, S. (2018). Esi- ja alkuopetuksen kulttuuriset tehtävät kuvataiteen ja käsityön näkökulmista. Teoksessa S. Rusanen, K. Rintakorpi, M. Kuusela \& K. Torkki (toim.), Mun kuvista kulttuuriin. Kuvataidetta esi- ja alkuopetukseen (ss. 156-171). Helsinki: Lasten Keskus.

Kangas, M. (2010). Finnish children's views on the ideal school and learning environment. Learning Environments Research, 13(3), 205-223. https://doi.org/10.1007/s10984-010-9075-6

Karjalainen, A. (1986). J.A. Hollon tiedekäsityksestä ja kasvatuksen teorian metodista. Näköaloja kasvatustieteen tutkimuskäytännön edistämiseksi etsivä metodologinen 


\section{Ainedidaktiikka 4(2) (2020)}

pohdinta. Oulun yliopiston kasvatustieteiden tiedekunnan tutkimuksia. Oulu: Oulun yliopisto.

Knif, L. \& Kairavuori, S. (2018). Moninaisen todellisuuden tutkijat - monilukutaitoa ja nykytaidetta alkuopetuksessa. Teoksessa S. Rusanen, K. Rintakorpi, M. Kuusela \& K. Torkki (toim.), Mun kuvista kulttuuriin. Kuvataidetta esi-ja alkuopetukseen (ss. 84-98). Helsinki: Lasten Keskus.

Kumpulainen, K., Lipponen, L., Hilppö, J. \& Mikkola, A. (2014). Building on the positive in children's lives: A co-participatory study on the social construction of children's sense of agency. Early Child Development and Care, 184(2), 211-229. https://doi.org/10.1080/03004430.2013.778253

Kumpulainen, K., Mikkola, A., Rajala, A., Hilppö, J. \& Lipponen, L. (2014). Positiivisen pedagogiikan jäljillä: Myönteisten kokemusten neuvottelu osana lasten oppimista ja hyvinvointia edistävää työtä. Teoksessa L. Uusitalo-Malmivaara (toim.), Positiivisen psykologian voima (ss. 224-242). Jyväskylä: PS-Kustannus.

Kumpulainen, K. (2018). A Principled, personalised, trusting and child-centric ECEC system in Finland. Teoksessa S. L. Kagan (toim.), The Early Advantage 1: Early Childhood Systems That Lead by Example (ss.72-98). New York: Teachers College Press.

Kumpulainen, K., Sintonen, S., Vartiainen, J., Sairanen, H., Nordström, A., Byman, J., \& Renlund, J. (2018). Kurittomat palaset: Monilukutaitoa opitaan ilolla. Helsinki: Helsingin yliopisto. http://hdl.handle.net/10138/264091

Laine, M. (2013). Kulttuurin saamat merkitykset kestävää kehitystä edistävän kasvatuksen näkökulmasta. Teoksessa M. Laine \& P. Toivanen (toim.), Kestävä kasvatus - kulttuuria etsimässä (ss. 26-38). Helsinki: Suomen Kulttuuriperintökasvatuksen seura.

Lawrence, R. L. \& Paige, D. S. (2016). What Our Ancestors Knew: Teaching and Learning Through Storytelling. New Directions for Adult and Continuing Education, 2016(149), 63-72. https://doi.org/10.1002/ace.20177

Lipponen, L. (2016). Tutkiva oppiminen varhaispedagogiikassa. Teoksessa E. Hujala \& L. Turja (toim.), Varhaiskasvatuksen käsikirja (ss. 31-38). Jyväskylä: PS-kustannus.

New London Group. (1996). A pedagogy of multiliteracies: Designing social futures. Harvard Educational Review, 66(1), 60-92. https://doi.org/10.17763/haer.66.1.17370n67v22j160u

Nicholson, S. (1971). How not to cheat children: The theory of loose parts. Landscape Architecture, 62, 30-35.

Nordström. A., Kumpulainen, K. \& Potter, J. (2019). Positive affect in young children's multiliteracies learning endeavours. Teoksessa K. Kumpulainen \& J. SeftonGreen (toim.), Multiliteracies and Early Years Innovation: Perspectives from Finland and Beyond (ss. 166-182). London: Routledge. https://doi.org/10.4324/9780429432668

Onnismaa, E.-L. \& Paananen, M. (2019). Varhaiskasvatuksen opetussuunnitelmatradition muotoutuminen Suomessa 1970-luvulta 2010-luvulle. Teoksessa T. Autio, L. Hakala \& T. Kujala (toim), Siirtymiä ja ajan merkkejä koulutuksessa. Opetussuunnitelmatutkimuksen näkökulmia (ss. 189-220). Tampere: Tampereen yliopisto. http://urn.fi/URN:ISBN:978-952-359-008-3

Opetushallitus (2014). Esiopetuksen opetussuunitelman perusteet 2014. Helsinki: Opetushallitus.

Opetushallitus (2018). Varhaiskasvatussuunitelman perusteet 2018. Helsinki: Opetushallitus.

Patton, M. Q. (2002). Qualitative Research \& Evaluation Methods. Integrating Theory and Practice. Thousand Oaks, CA: Sage.

Pautola, L. (1955). Professori J.A. Hollo. 70-vuotias. Esipuhe. Teoksessa Juhlakirja professori J.A. Hollon 70-vuotispäiväksi 17.1.1955. Helsinki: Suomen kasvatusopillinen yhdistys.

Pekrun, R., Elliot, A. J. \& Maier, M. A. (2006). Achievement goals and discrete achievement emotions: A theoretical model and prospective test. Journal of Educational Psychology, 98(3), 583-597. https://doi.org/10.1037/0022-0663.98.3.583

Puolamäki, L. (2008). Perintönä ympäristö. Teoksessa P. Venäläinen (toim.), Kulttuuriperintö ja oppiminen (ss. 58-65). Suomen museoliiton julkaisuja 58. Helsinki: Suomen museoliitto. 


\section{Ainedidaktiikka 4(2) (2020)}

Puolimatka, T. (1999). Kasvatuksen mahdollisuudet ja rajat. Minuuden rakentamisen filosofia. Helsinki: Kirjayhtymä.

Rauhala, L. (2009). Henkinen ihminen. Henkinen ihmisessä ja ihmisen ainutlaatuisuus. Helsinki: Gaudeamus.

Rauste-von Wright, M. \& von Wright, J. (1994). Oppiminen ja koulutus. Helsinki: WSOY.

Räsänen, M. (2010). Taide, taitaminen ja tietäminen - kokonaisvaltaisen opetuksen lähtökohtia. Teoksessa E. Ropo \& H. Silfverberg \& T. Soini (toim.), Toisensa kohtaavat ainedidaktiikat. Ainedidaktiikan symposiumi Tampereella 13.2.2009 (ss. 339-354). Tampere: Tampereen yliopisto. http://urn.fi/urn:isbn:978-951-44-8011-9

Sairanen, H. \& Kangas, J. \& Sintonen, S. (2019). Finnish Teachers Making Sense of and Promoting Multiliteracies in Early Years Education. Teoksessa K. Kumpulainen \& J. Shefton-Green (toim.), Multiliteracies and Early Years Innovation: Perspectives from Finland and Beyond (ss. 42-60). London: Routledge. https://doi.org/10.4324/9780429432668-3

Sihvonen, J. (1996). Aineeton syli. Johdatus audiovisuaaliseen tulevaisuuteen. Helsinki: Gaudeamus.

Sintonen, S. (2017). Lempeällä otteella monilukutaitoa. Blogikirjoitus 23.8.2017. Saatavilla http://www.monilukutaito.com/blog/38/lempealla-otteella-monilukutaitoa

Stark, E. (2016). Arkistopedagogiikka - Arkistot historiatulkintojen oppimisympäristöinä. Kasvatus \& Aika, 10(2), 68-76.

https://journal.fi/kasvatusjaaika/article/view/68633

Suoranta, J. (1996). Juho A. Hollon neljä elämään. niin \& näin, 2/1996, 53-55. https://netn.fi/artikkeli/juho-a-hollon-nelja-elamaa

Säljö, R. (2001). Oppimiskäytännöt-sosiokulttuurinen näkökulma. Helsinki: WSOY.

Taneli, M. (2012). Kasvatus on kasvamaan saattamista. Kasvatusfilosofinen tutkimus J. A. Hollon sivistyskasvatusajattelusta. (Väitöskirja). Turun yliopisto. http://urn.fi/URN:ISBN:978-951-29-5192-5

Uljens, M. (2007). J.A. Hollo - pluralistisen yleisen kasvatustieteen edustaja. Saatavilla http://www.vasa.abo.fi/users/muljens/pdf/hollo.pdf

Vygotsky, L. S. (1976). Play and its role in the mental development of the child. Teoksessa J. Bruner \& A. Jolly \& K. Sylva (toim.), Play: Its role in development and evolution (ss. 76-99). New York: Basic Books.

Värri, V.-M. (2014). Halun kultivointi ekologisen sivistyksen mahdollisuutena. Teoksessa A. Saari \& O.-J. Jokisaari \& V.-M. Värri (toim.), Ajan kasvatus. Kasvatusfilosofia aikalaiskritiikkinä (ss. 87-122). Tampere: Tampere University Press.

Willamo, R. (2005). Kokonaisvaltainen lähestymistapa ympäristönsuojelutieteessä. Sisällön moniulotteisuus ympäristönsuojelijan haasteena. (Väitöskirja). Helsingin yliopisto. http://urn.fi/URN:ISBN:952-10-2527-1 